Article

\title{
Urban Sprawl Risk Delimitation: The Concept for Spatial Planning Policy in Poland
}

\author{
Piotr Lityński (iD) and Artur Hołuj *iC \\ Department of Spatial Management, Faculty of Economy and Public Administration, Cracow University of \\ Economics, 27 Rakowicka St., 31-510 Cracow, Poland; litynskp@uek.krakow.pl \\ * Correspondence: holuja@uek.krakow.pl
}

Received: 3 March 2020; Accepted: 24 March 2020; Published: 26 March 2020

\begin{abstract}
Urban sprawl is a process shaping the space of contemporary urban areas. The costs generated by this phenomenon force central and local authorities to adopt and implement a spatial policy limiting those costs. However, there is no method in Polish spatial policy that determines the extent of this phenomenon around cities, and thus identifies the area of intervention. Therefore, the purpose of the article is to propose a method of delimitation of urban areas at risk of urban sprawl. The proposed method of delimitation honors the characteristics of urban sprawl relating to spatial structure, socio-economic processes and efficiency of spatial policy. The method can be useful for conducting spatial policy aimed at reducing costs due to urban sprawl. It particularly pertains to the policy implemented at the central and regional level. Research results indicate that, in most Polish urban areas, delimitations used thus far designate too little of the area around core cities. Although the goals of reducing the negative consequences of urban sprawl are formulated at the level of national spatial policy, the methods of delimitation used thus far do not take into account the specificity of this phenomenon. Underestimating the extent of urban sprawl results in a lack of effectiveness of spatial policy due to the omission of specific areas in public intervention. This particularity is related to the fact that these are usually external areas-the most distant from the core city. These areas have the highest costs for urban sprawl. At the same time, these are areas in the early stages of spatial growth, in which a consistent spatial structure can still be kept while implementing proper spatial policy.
\end{abstract}

Keywords: spatial planning policy; urban sprawl; delimitation; cities; functional areas

\section{Introduction}

Spatial planning policy is the domain of public entities, and commune governments generally play a special role in actively influencing the structure of space. In Poland, the commune authorities are responsible for space management at the local level, but their authority is limited by the administrative boundaries of the commune. It is widely recognized in Poland that the commune self-government is struggling with the implementation of effective spatial planning policy. The current spatial planning system is assessed as inefficient $[1,2]$. There are legal gaps that prevent the implementation of good practices in spatial management, taking into account economic and urban legitimacy. Hence, ensuring the implementation of the basic objectives of spatial policy, which are maintaining spatial order and sustainable development, is becoming increasingly difficult [3-5]. Systemic problems are accompanied by dynamically occurring social, economic and spatial processes. These processes occur most strongly in metropolitan areas, resulting in an undesirable spatial structure known as urban sprawl.

Urban sprawl is one of the processes of the natural spatial evolution of the city, caused by economic development and an increase in household income. It is also the dominant form of spatial growth in 
the cities of Poland [6]. Therefore, the public sector should adapt to the new circumstances and needs generated by this process, adopting an effective spatial policy. Since urban sprawl is a phenomenon that goes beyond one commune, regional and central government entities also play an important role in its coordination. As part of their spatial policy, the instruments used should consider the issues of urban sprawl. An important element for efficient space management is, however, a clear indication of the extent of the impact of urban sprawl [7,8]. It is necessary to make a scientifically satisfactory delimitation specifying the occurrence of the phenomenon. This will allow spatial identification of, and further intervention in the activities of, the areas covered by the analyzed phenomenon.

The aim of this study is to propose a method of urban sprawl risk delimitation, and the empirical examples are the most important Polish cities-regional capitals. The proposed method of delimitation captures the specificity of the process and state of urban sprawl. The delimitations functioning in Polish spatial planning policy do not fully reflect the issues of spontaneous urban sprawl. Existing variations in conceptual and methodological delimitation do not classify urban sprawl. Nevertheless, the article discusses the delimitation of urban sprawl against the background of the delimitation of functional urban areas (FUAs) and integrated territorial investment (ITI) already occurring in the literature. The justifications for taking up this subject are the equally dynamic spatial changes occurring in Poland, generating the need for discussion on the methodology of delimitation of urban sprawl around large cities, which will allow for the formulation and implementation of active spatial policy going beyond the administrative boundaries of one commune.

\section{Current State of Knowledge}

From the point of view of the issue of delimitation, urban sprawl in the first place requires reflection, necessary to discuss the specificity of urban sprawl as a spatial phenomenon. It is then possible to discuss the delimitation of this phenomenon. This is also the order in which the content is presented in this paper.

Urban sprawl is a term which was introduced into science in 1937 by E. Draper during an urban conference in the United States $[9,10]$. Since then, the term has spread to many disciplines, but without the effect of a common and agreed definition [11-15]. This is due to the phenomenon being different in many countries. It describes diversity in the specificity of the spatial structure, its dynamics, and socio-economic and environmental consequences [16-19]. Galster et al. [20] criticize the terminological ambiguity of urban sprawl, indicating that much of the literature is "lost in the semantic wilderness", and the term is so vague in definition that some researchers admit that "they recognize sprawl when they see it". Bhatta [21] (p. 8) notes that there are discussions in the literature on urban sprawl even without any description that approximates the essence of this issue.

In the presented study, urban sprawl was defined on the basis of the achievements of Galster et al. [20], Arribas-Bel, Nijkamp and Scholten, [22] and Perrsky and Wiewel [23]. In the context of this literature, urban sprawl is a chaotic change in the spatial structure of suburban communes, which arose as a result of the intensification of suburbanization, with a low degree of control of these processes on the part of spatial policy. Urban sprawl can be treated both statically as a way of developing space, that is, the specific spatial configuration of the urban area at a given moment; and as a process, i.e., change in the spatial structure of the urban area over time.

The static approach makes it possible to understand the spatial distribution of buildings at the adopted moment in the studied area. In the literature, the characteristics of urban sprawl presented by Galster et al. [20] are highly recognized [22,24]. In this approach, urban sprawl is a space structure that is characterized by:

- low building density;

- lack of spatial continuity between existing buildings;

- lack of concentration of buildings in a relatively small area;

- no grouping of buildings into compact settlements; 
- $\quad$ spatial decentralization associated with large building distances from the city center;

- polynuclearity reflecting the multitude of settlements;

- lack of functional differentiation of land use;

- lack of proximity, i.e., proximity of functionally different types of land.

The dynamic approach makes it possible to understand the changes taking place in the space of suburban communes due to the intensification of suburbanization. The dynamics of urban sprawl can be explained from the point of view of the theory of spatial growth of the urban area. According to Herold et al. [25] the expansion of the urban area begins with a core that spreads to new, single, non-adjacent settlements. Further development and continuation of the spatial evolution of the urban area is associated with the development of areas between settlements, and thus combining the structure of space into a more compact and spatially continuous development. This diagram suggests that certain parts of the urban area may undergo an expansion phase before eventually forming a compact spatial structure that can no longer be characterized as disordered. However, from this point of view, determining the place, time and form of urban sprawl becomes ambiguous. Therefore, urban sprawl cannot be characterized as a process without first considering its state. Rather, urban sprawl should be considered in the light of successive states of spatial structure over a period of time. Only an assessment of the direction of changes in the structure of space reveals positively valued spatial development or negative transformations.

Consideration of urban sprawl as a dynamic process complicates its identification, due to the need to adopt an appropriate territorial scale. This refers to considering the geographical scope of the process, which shifts outwardly from the core at different times. Generally, in empirical research on urban sprawl, previously eliminated metropolitan areas functioning in the real sphere are considered [26-28]. It should be noted that metropolitan areas are convenient for researchers, due to the availability of appropriately aggregated data, but at the same time show the shortcomings of overestimating or underestimating the range of urban sprawl discussed in the literature. The revaluation eliminates the risk of adopting the phenomenon boundary too narrowly. On the other hand, including peripheral municipalities may slightly disturb the assessment [29-32]. There are, therefore, in research, arbitrary approaches to the adoption of boundaries that go beyond the urbanized area at a heuristically determined distance to attempt to capture the phenomenon. Such an approach may, however, ignore places beyond the arbitrary demarcation line, which are sufficient from the urban sprawl point of view; i.e., they show satisfactory functional connections with the core and the associated space changes. Therefore, the research should adopt a territorially appropriate delimitation method based on indicators demonstrating the occurrence of urban sprawl. On the other hand, the evaluation of indicators (i.e., determining the qualifying level) may take place by means of heuristic methods due to the territorial diversity and regional specificity of the process (e.g., the monocentric or polycentric nature of a metropolis; the number of centers in a polycentric system; terrain; occurrence of water reservoirs; time and costs of travel to the core city; historical background of settlement; etc.) [33].

In Poland, in the years 1964, 1969, 1971, 1972, 1980, 1989, 2005, 2007 and 2009, a number of delimitations of metropolitan areas as well as metropolitan and urban-industrial agglomerations occurred [34-42]. Originally, in the 1960s, analysis was mainly based on population density, and in the 1970s, it was clearly expanded to include housing conditions, a change in the number of inhabitants, employment outside agriculture, permanent migration and commuting. In the 1990s, research also included the structure of business entities and entrepreneurship, as well as gravitational aspects. Along with the improving statistics available after 2000, the criteria of spatial accessibility (i.e., travel time and commuting to schools) were an additional supplement.

In the literature on delimitation, Ratzel was one of the first to separate areas where identical phenomena occur. He was the precursor of the theory of the occurrence of the core in agglomeration as well as suburban and peripheral areas [43]. Hoover wrote about problem areas in the 1940s. In his work, areas of overly high concentration and development were indicated: backward and retreating [44]. The delimitation proposed by Alonso and Friedmann is also significant, indicating the spaces in which 
developmental processes/slowdowns and their associated core areas occur [45]. They distinguished a core with significant development potential closely related to development axes embedded along major communication routes (formed between core areas). They also indicated the boundary space (currently, we include suburbs) and depressive space/region (area of depopulation, stagnation of economic development). In addition, various delimitations or classifications of areas/regions according to their functions, changes, development/growth, generated problems, etc., have been carried out over the years. Compare, among others, [46-58].

Therefore, experience in the field of delimitation methodology in Poland and in the world has a long history and rich achievements [59-64]. Despite this, due to individual assumptions and the choice of indicators and criteria, these delimitations are usually incomparable with each other [65]. Similar conclusions can be found in the literature. Goerlich et al. [66] concludes that urban delimitation remains a challenge and that no standardized method has been developed. Liang et al. [67] comes to similar conclusions making a broad review of literature on delimitation. Therefore, in the context of the delimitation of urban sprawl, Tellier and Gelb [68] indicate that the development of one mathematical tool remains as an unreachable dream for most researchers.

In research on both the delimitation and spatial specificity of urban sprawl, the most commonly used measure in the literature is density and its changes, regarding development, housing, employment, services, etc. [29,32,69-73]. When reviewing methodological approaches in Poland, Pieniazzek and Rogalińska [74] emphasize that there is a gap in the comprehensive approach in the field of urban sprawl. Pieniążek and Rogalińska [74] emphasize that in Polish conditions (i.e., using statistical data available in official statistics) delimitation is currently limited to population processes related to migration processes, changes in the state and structure of the population, and building growth.

From the point of view of Polish spatial planning policy attempts to influence urban sprawl, two separately applicable delimitations are important: functional urban areas of regional capitals (FUAs) and integrated territorial investment (ITI). The FUA delimitation was prepared for the needs of a governmental document: the National Spatial Development Concept 2030 (NSDC 2030), which is the most important national strategic document on Poland's spatial development. The document draws attention to Objective 6. Restoring and consolidating spatial order, which, among other things, focuses on building a spatial planning system of functional areas to prevent negative effects of urban sprawl. FUA delimitation is based on seven indicators reflecting functional connections, and socio-economic and morphological features:

1. Leaving for work to the FUA core;

2. Migration (registration) from the FUA core;

3. Share of persons employed in non-agricultural occupations;

4. Intensity of economic entities (in relation to the population);

5. Share of business entities belonging to higher-order services in the total number of entities;

6. Population density (excluding forests and waters);

7. Newly built housing in relation to the population.

A necessary condition was to meet six of the seven indicators listed. Meeting the criterion meant reaching threshold values that were set arbitrarily. The authors notice that setting thresholds is subjective. However, in the light of the previously cited literature, some discretion in this respect can be considered justified [58]. On the other hand, the ITI delimitation was to provide conditions for a partnership model of cooperation between local government units in spending EU funds. It refers to investments-especially infrastructural ones-whose scope goes beyond the borders of one commune. The ITI delimitation procedure was based on several relatively different formulas, i.e., based on:

1. Recommendations of the Ministry of Regional Development of Poland (the FUAs of these cities: Białystok, Gorzów Wielkopolski, Lublin, Olsztyn, Rzeszów, Zielona Góra and Wrocław);

2. Strategic studies of regions (the FUAs of the Central Subregion and Łódź); 
3. Prior cooperation of communes (the FUAs of Trójmiasto, Poznań and Szczecin);

4. Expertise (the FUAs of Bydgosko-Toruński and Kielce);

5. The decision of the ITI association (the FUAs of Kraków, Opole and Warszawa).

Therefore, it seems that for the effectiveness of spatial planning policy and scientific research, an attempt to delimitate urban sprawl in Poland should be made. Verification of the territorial scope of the delimitation of FUA and ITI is justified by the previously mentioned problem of underestimation, which may result in non-intervention by peripheral communes. These are communes which, on the one hand, are particularly exposed to the negative effects of urban sprawl, and on the other, their current state of development allows for limiting the chaotic location of buildings.

The theoretical framework for the urban sprawl delimitation procedure can be found in the so-called Urban Metric System (the UMS). The UMS is embedded in the rich theoretical achievements of spatial planning, starting from the concept of von Thünen. Since the mid-1980s, the UMS has been developed by L.-N. Tellier [75-79]. Tellier, based on the achievements of von Thünen and Weber, formulated the problem of attraction-repulsion. It should also be noted here that Ottaviano and Thisse [80] define the problem of attraction and repulsion forces as the foundation of the New Economic Geography proposed by Krugman in the 1990s. The problem of attraction and repulsion forces boils down to finding, in the geographical space, the optimal location of point $\mathrm{D}$ relative to the triangle of points A1, A2 (Attraction) and R (Repulsion). Optimality is understood as equating the weight of the repulsive force generated by $\mathrm{R}$ with the weight of the attractive forces exerted by $\mathrm{A} 1$ and $\mathrm{A} 2$. In the years 2017-2018, Tellier proposed the final UMS model, which allows mathematical delimitation of urban sprawl using the spatial distribution of residents and jobs. In the assumptions of the model [68], every household and business entity in each zone of the urban area is characterized by equally high preferences for a location in the city center. Because not all entities can take a location in the city center, for spatial and financial reasons (business entities are willing to pay a higher price for a central location than households), each entity is forced to consider a different, external location. This location, however, shows varying costs of transport to the city center, which has the largest share of jobs. Increasing transport costs along with the distance affect both the reduction of land prices and prices of residential buildings. Thus, from the point of view of real estate prices, the city center exerts a repulsive force on individuals, and suburbs an attracting force. The urban sprawl delimitation is therefore the result of the interaction of attractive and repulsive forces, and ultimately the units are located where the net result of attractive and repulsive forces is zero. The boundary of the urban area is determined by the "zero resultant radius", that is, the distance at which the repulsive effect starts to exceed the attractive factors.

\section{Materials and Methods}

The starting point for the proposed method of delimitation is the cited definition of urban sprawl, i.e., "chaotic changes in the spatial structure of suburban communes resulting from the intensification of suburbanization, with a low degree of control of these processes on the part of spatial policy." This definition reveals the necessity to measure the spatial structure, but also the causes of the phenomenon, related to migration processes and spatial policy. The latter, indicating the reasons, can be the basis for signaling the process. They do not ultimately determine whether this phenomenon actually occurs, because it requires the identification of the spatial structure but may indicate delimitation. At the same time, the question arises about the communes that should be examined (i.e., how far from the core city to reach in the study).

Considering the above, two stages of delimitation were adopted: the first setting the maximum range of research; the second within the designated range are studies on the possibility of urban sprawl. 


\subsection{The Maximum Research Range}

The first stage includes two basic conditions. The first condition concerns the need to indicate the communes surrounding the city core based on the radius. A radius was proposed which does not refer to a straight line (e.g., $10 \mathrm{~km}, 20 \mathrm{~km}$, etc.) as sometimes can be found in separate studies [68,81], but one which is determined by the availability of time [82]. It was assumed that communes should be located within an hourly reach of the core city, which was determined on the basis of Google Maps' tools, by reading the travel time between the commune and the core city's borders. Jobs have been adopted as attracting forces to the city. On the other hand, the effect that repels people from the city and attracts to the suburbs is the preference of households, which are materialized in a suburban location. On the other hand, the hourly equivalent cost of traveling by car to the city limits was assumed as a repulsive effect from suburbs. Assuming a passenger car depreciation rate of $0.8358 \mathrm{PLN} / \mathrm{km}$ [Regulation of the Minister of Transport 2007], daily hourly journeys to the borders of the core city absorb about $50 \%$ of the average salary. Individual calculations were carried out for each of the analyzed urban areas. Thus, the travel time was assumed to be zero resultant radius. It should be noted that the time and value of travel to work inside the city, which would de facto raise the $50 \%$ threshold due to congestion and the generally significant size of the core city, were not taken into account. The second group of assumptions are that as part of the city's spreading processes, suburban buildings may develop in the absence of commuting to the city. These are residents employed locally or conducting local business activities. In this situation, flows between the municipalities of the external zone are identified. However, the inhabitants still express their preferences for being influenced by the city's socio-economic power.

\subsection{Urban Sprawl Possibility}

The starting point for the second stage is the area defined by the zero-resultant radius. In this area, a research procedure was carried out, the results of which indicates the possibility of urban sprawl. The final result of delimitation understood in this way is a set of communes that are common to both discussed stages of designation of research areas. In the second stage, the definition of urban sprawl was used. The subject of methodological operationalization is, therefore, the selection of variables for three groups: settlement structure, migration processes, and spatial policy efficiency. These will be discussed later.

For describing the characteristics of the variables, the measures of state and dynamics used in the assessment of communes should be explained. These measures are a suggestion of mathematical tools, instead of arbitrarily setting thresholds for identifying urban sprawl. A moving average $\left[\mathrm{S}_{(\mathrm{n}, \mathrm{k})}\right]$ was proposed to capture the state of the phenomenon. The moving average using historical data determines the main trend. The moving average value is a smoothing over time of input data changes, (i.e., filtering random movements of the values of the examined features). However, to capture the dynamics of urban sprawl, the so-called chain dynamics index $\left[\mathrm{I}_{\mathrm{G}}\right]$ is employed. Using this index, which is a measure of the dynamics of the time series, the degree of changes in the level of the phenomenon of urban sprawl in relation to the previous period is indicated. The index is equal to one when the level of the phenomenon is the same in both periods. The interpretation indicates that its value is assessed based on the relation to number 1 , where the numbers show the dynamics of the examined process: numbers $>1$ show an increase; numbers $=1$ show stagnation; while numbers $<1$ show a fall. It is assumed that the process occurs when the index $>1$, and the higher the index value above 1 , the more clearly identifiable the process is. However, if the index $<1$, then the opposite process occurs.

\subsubsection{Settlement Structure}

Reverting back to explaining the selection of variables, first of all, attention is paid to the assessment of the settlement structure, which refers to a fragment of the definition of "The process of chaotic changes in the spatial structure of suburban communes...". Therefore, the following were proposed 
as variables: (1) new buildings completed; (2) number of apartments per $1 \mathrm{k}$ residents. The selection of variables results from the features of space development processes that accompany urban sprawl. Schneider and Woodcock [83] identify changes in space development use, including, among others, in the spatial extent of urban areas and new urban land indicators. Their research is primarily on new construction investments in metropolitan areas, with particular emphasis on residential developments. Thus, variable new buildings completed is a feature that reflects the total construction activity. Increasing values of $\mathrm{I}_{\mathrm{G}}>1 ; \mathrm{S}_{(\mathrm{n}, \mathrm{k})}>0$ signal urban sprawl. On the other hand, the number of flats per $1 \mathrm{k}$ residents reflects the number of all inhabited and uninhabited housing units on the market (i.e., buildings dedicated to both indigenous and incoming inhabitants of the commune). For this variable, the values $\mathrm{I}_{\mathrm{G}}>1$ and $\mathrm{S}_{(\mathrm{n}, \mathrm{k})}>0$ indicate the possibility of urban sprawl.

\subsubsection{Migration Processes}

The second group of variables relates to migration processes and concerns a fragment of the definition of "...as a result of the intensification of suburbanization..." (movement of people and companies to the suburbs.) Two subgroups were proposed in this group of variables. The first refers to households and distinguishes: (1) registrations from city; (2) balance of internal migration. These variables are recognizable in the literature on the subject of urban sprawl delimitation. Heffner [84], for the assessment of suburbanization processes of the population in Poland, uses, among other things, the balance of migration and outflow from the city to the countryside, while jumping to the justification of the study of these variables. The selection of variables in the proposed method within the first subgroup involves the need to present both the causes of urban sprawl and the necessary condition for this phenomenon: residents moving from cities to surrounding municipalities. Thus, the variable related to registration allows for demonstrating a change in the place of residence and signals the direction of relocation of residents, where the original place of residence of the person newly registered in the commune could be the core city. The values of $\mathrm{I}_{\mathrm{G}}>1$ and $\left.\mathrm{S}_{(\mathrm{n}, \mathrm{k}}\right)>0$ indicate that people are moving to the communes surrounding the core city. The second variable—migratory—displays changes resulting from migration in the population living in the studied areas. The values of indicators $\mathrm{I}_{\mathrm{G}}>1$ and $\mathrm{S}_{(\mathrm{n}, \mathrm{k})}>0$ indicate that the commune is interested in both indigenous and core city households. Low values of $\mathrm{I}_{\mathrm{G}}<1, \mathrm{~S}_{(\mathrm{n}, \mathrm{k})}<0$ can be identified with the opposite process. The second subgroup concerns economic activity and includes the number of newly registered business entities. It should be clarified that the second subgroup refers to the assessment of spatial deconcentration of economic activity as an urban sprawl factor. This measure complements the analysis of population migration to the suburbs by observing the shift in economic activity to suburbs [9,85-88]. The combination of both subgroups of indicators is important to capture the spread of the city to suburban areas, due to the spatial decentralization of urban functions over time $[89,90]$. Thus, the proposed variable is closely related to the changes occurring in the local economy in connection with the movement of the population and should be considered especially in the context of the increasing or decreasing demand for goods and services and the supply of jobs. The rank of the indicator is also raised by the fact that market conditions are the final regulator of local changes, because a larger number of inhabitants triggers a higher demand for goods and services, and thus for the creation of new business entities. Therefore, the values of the indicators $\mathrm{I}_{\mathrm{G}}>1$ and $\mathrm{S}_{(\mathrm{n}, \mathrm{k})}>0$ demonstrate the possibility of urban sprawl.

\subsubsection{Spatial Policy Efficiency}

The third group of variables concerns the efficiency of spatial policy and refers to the fragment of the quoted definition: "...with a low degree of control on the part of spatial policy." For this group of variables the following were proposed: (1) administrative decisions on construction conditions; (2) coverage of local spatial development plans (LSDP) as a share of the commune area with plans. The lack of efficiency of public authorities in space management is emphasized in the cited definition, but also in other studies cited in the first chapter related to the spontaneity of spatial processes. In the context of the process under consideration, however, there are no records in the literature measuring 
this performance. This is due to the historical and territorial context of the phenomenon, and therefore the differences between the Polish and the global specificity. That is why unique indicators were proposed. One variable, administrative decisions on construction conditions (single and multi-family housing, services and associated buildings), indicates urbanization pressure in space. Because these decisions are issued in the absence of spatial plans, it can also be an expression of the low effectiveness of spatial policies designing and implementing local spatial development plans. However, the issuing decisions on building conditions are legal, but they are usually accompanied by chaos in spatial development [91,92]. Therefore, the values of indicators $I_{G}>1$ and $S_{(n, k)}>0$ signal the possibility of urban sprawl. As regards the local spatial development plan, it can be assumed that the high share of local plan coverage demonstrates efficient and thoughtful spatial policy. Therefore, the values of indicators $\mathrm{I}_{\mathrm{G}}>1$ and $\mathrm{S}(\mathrm{n}, \mathrm{k})>50$ demonstrate to the control of spatial processes, and therefore the low level of probability of chaotically spatial processes in the commune. For the values of indicators $\mathrm{I}_{\mathrm{G}}<1$ and $\mathrm{S}_{(\mathrm{n}, \mathrm{k})}<50$ it was assumed that there are favorable circumstances for the occurrence of spontaneous location.

\subsubsection{Data, Techniques and Criteria Used}

The above variables were calculated on the basis of the statistical data of the Central Statistical Office of Poland for the periods indicated in Table 1. In addition, correlation analyzes were carried out within three groups (e.g., var.1 with var.2). On the other hand, no correlation was analyzed in the entire set (e.g., var.1 with var.4) for substantive reasons; i.e., they represent separate definitions of characteristics. Correlation coefficients were satisfactory.

Table 1. Time range of selected variables.

\begin{tabular}{lc}
\hline \multicolumn{1}{c}{ Variable } & Period \\
\hline 1. New buildings completed & $2009-2016$ \\
2. Number of apartments per 1k residents & $2003-2014$ \\
3. Registrations from city & $1995-2016$ \\
4. Balance of internal migration & $1995-2016$ \\
5. Newly registered business entities & $2009-2016$ \\
6. Administrative decisions on constructions conditions & $2009-2016$ \\
7. Coverage of LSDP & $2009-2016$ \\
\hline
\end{tabular}

The next step of delimitation was the construction of a synthetic index signaling the possibility of spontaneous urban spread for each of the communes separately. In this case, a common scale was proposed, giving comparability of different indicators. To this end, histograms were developed for all indicators, together with the adoption of the minimum and maximum interval value and its assessment (from 1 to 5). Benford analysis based on the Audit Command Language (ACL) software was used to analyze the indicators. The applied statistical module (ACL) allowed for the assessment of the number of occurrences of each leading digit or combination of numbers in the data set and comparison with the actual count in relation to the expected count [93]. Weights were developed for individual indicators (Table 2), which were established in a group of ten experts representing the specialization in economics, socio-economic geography and statistics.

The synthetic index was calculated separately for chain dynamics indices and separately for the moving average as the sum of weighted indices. The interpretation of urban sprawl dynamics on the basis of a synthetic index for the chain dynamics index indicates that, when $\mathrm{I}_{\mathrm{G}}$ is in the range $(0,1)$, the process of urban sprawl can be identified. On the other hand, when $\mathrm{I}_{\mathrm{G}}>1$, the process can be seen to a significant degree. With the increase of $\mathrm{I}_{\mathrm{G}}$ relative to the value of 1 , this process intensifies very dynamically. In turn, the interpretation of the phenomenon level based on the synthetic index for the moving average indicates that when $S_{(n, k)}$ is in the range $(-1.5,1)$ the phenomenon can be identified, but at a low level. However, when $S_{(n, k)}>1$, this phenomenon can be seen to a significant extent. 
With the increase of $S_{(n, k)}$ relative to the value of 1, the level of the phenomenon is growing dynamically. It was assumed that if the value of one of the indicators is greater than one, then the commune was included in those at risk of urban sprawl and should be included in delimitation.

Table 2. Weights for indicators of communes' selection.

\begin{tabular}{lcc}
\hline \multicolumn{1}{c}{ Variable } & $\mathbf{I}_{\mathbf{G}}$ & $\mathbf{S}_{(\mathbf{n}, \mathbf{k})}$ \\
\hline 1. New buildings completed & 0.2 & 0.2 \\
2. Number of apartments per 1k residents & 0.1 & 0.1 \\
3. Registrations from city & 0.2 & 0.2 \\
4. Balance of internal migration & 0.3 & 0.3 \\
5. Newly registered business entities & 0.1 & 0.1 \\
6. Administrative decisions on constructions conditions & 0.05 & 0.05 \\
7. Coverage of LSDP & 0.05 & 0.05 \\
\hline
\end{tabular}

Among the other formal criteria, the following were additionally used: belonging to the functional urban areas of the capitals of the regions mentioned in the theoretical part, and disjunction expressed by including the commune in only one designated area. The delimitation literature also applies the principle of compactness (i.e., including a commune surrounded by other meeting criteria) [94]. However, this rule was relaxed due to the characteristics of urban sprawl. It seems that the criteria should correspond to the features of spontaneous spatial changes, and the most important manifestations of the phenomenon include the lack of compactness.

\section{Results}

The result of the presented proposal of urban sprawl risk delimitation is a set of 382 communes around the regional core cities, which are shown in Figure 1. The communes resulting from the proposed delimitation constitute a set marked in yellow and red. Thus, all the indicated communes on map 1 (yellow and red) are the result of analyses using the delimitation discussed. What's more, the authors' analysis clearly indicates (red) the municipalities in which urban sprawl processes occur and which are not included in the national ITI delimitation. Therefore, these are municipalities requiring intervention, broadly understood, including their inclusion in relevant supporting government programs.
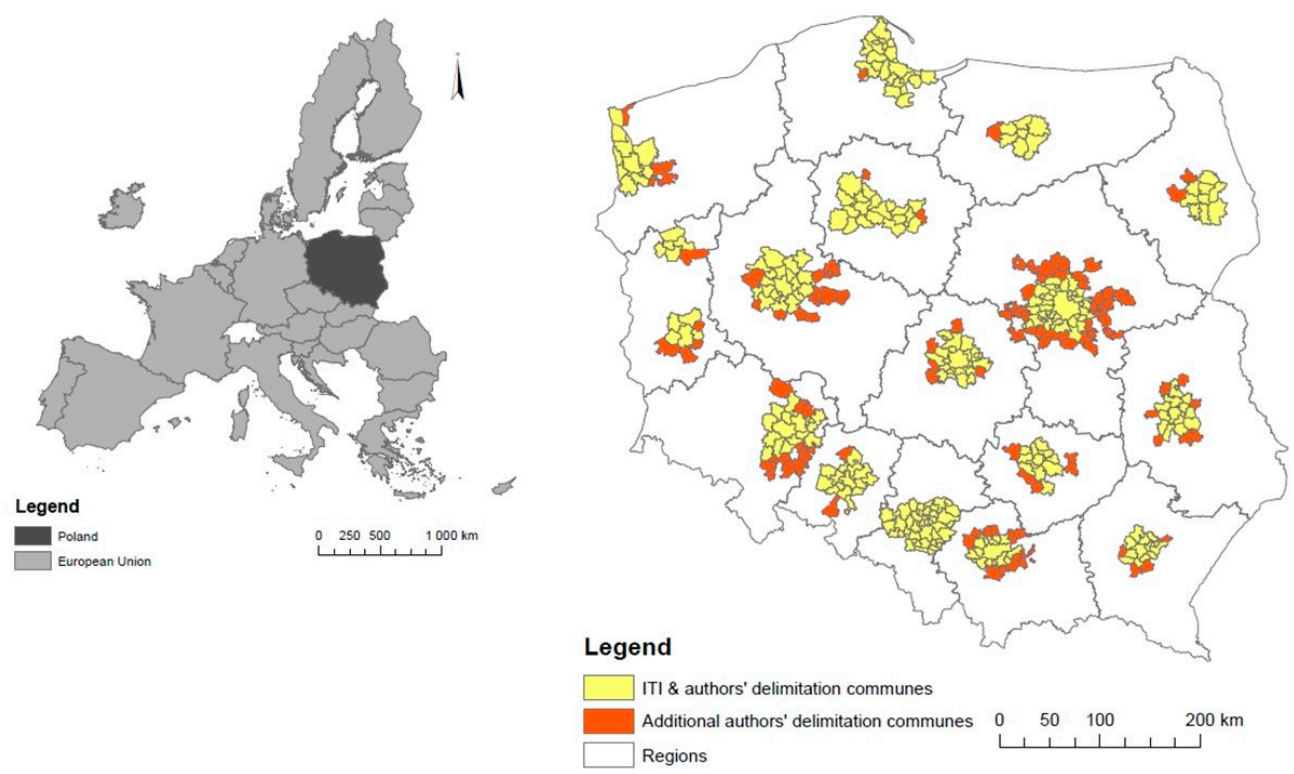

Figure 1. Set of communes under urban sprawl risk in Poland (authors' delimitation) (Source: Own elaboration). 
The proposed delimitation presented in Figure 1 is presented against the background of the two mentioned delimitations of FUA and ITI. The FUA delimitation includes 299 communes (266 in the external zone), while in the case of ITI it is 348 communes [94].

The proposed delimitation of urban sprawl risk generally extends beyond FUA and ITI. A certain exception is the broader delimitation of the FUA of the Central Subregion and the scope of the ITI (Figure 2). This fact is related to the functioning of the Upper Silesian Metropolitan Union, whose metropolitan core is created by 13 cities with province rights, i.e., Bytom, Chorzów, Dąbrowa Górnicza, Gliwice, Katowice, Mysłowice, Piekary Śląskie, Ruda Śląska, Siemianowice Śląskie, Sosnowiec, Świętochłowice, Tychy, Zabrze (Jaworzno with USMU in Jan. 2017). From the north, weights from the ITI Czestochowa are visible, and from the south, those from the ITI Rybnik and ITI Bielsko-Biała. In the authors' opinion, the structure of ITI indicated is not satisfactory in the socio-economic and integration relationships that occur.

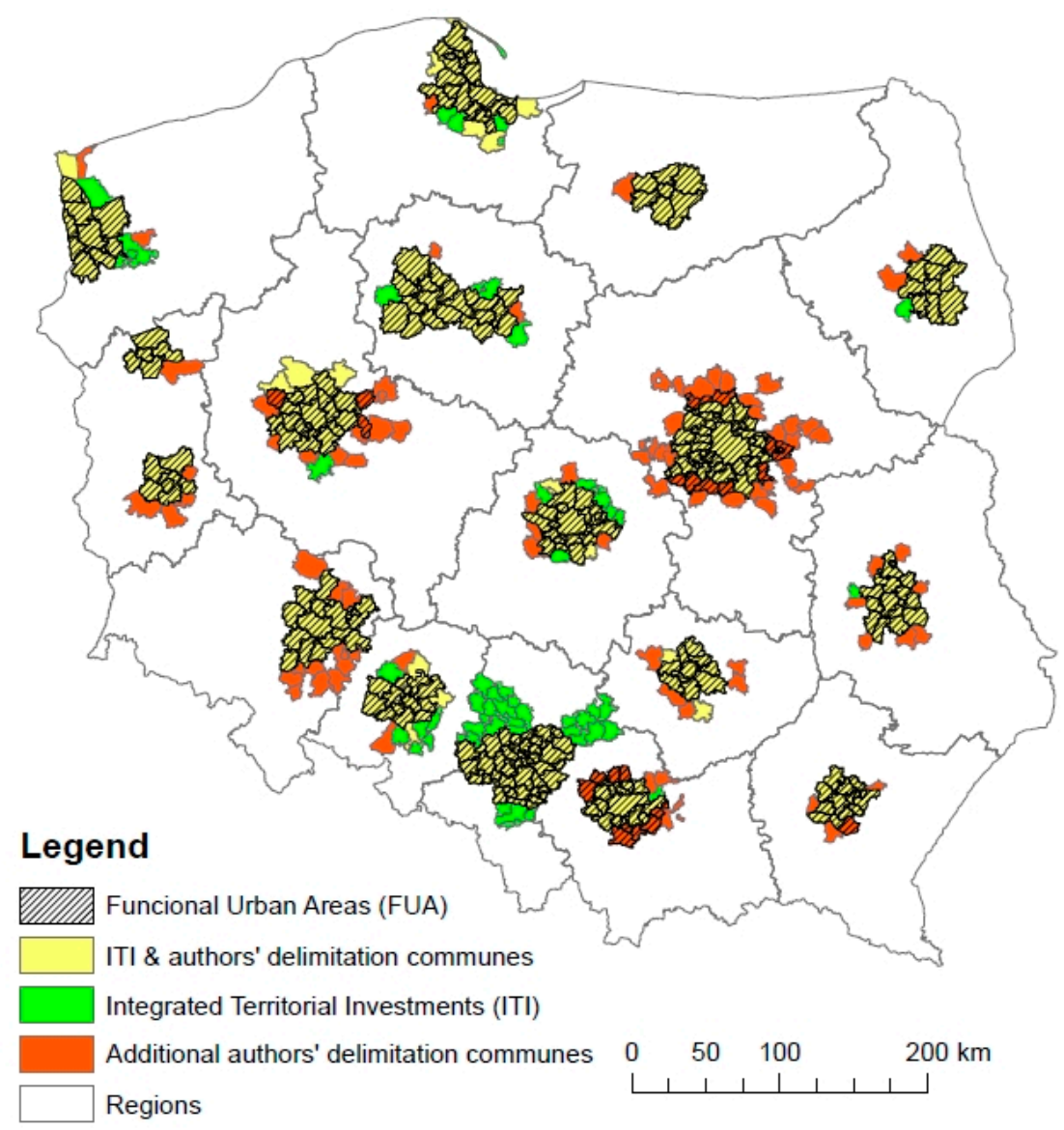

Figure 2. Set of communes under urban sprawl risk (authors' delimitation) against the background of FUA and ITI delimitations. (Source: own elaboration.)

In Figure 2, the municipalities designated in the authors' delimitation are marked with yellow and red in analogy to Figure 1. The communes additionally marked with black stripes are units established at the government level as FUA. In addition, green indicates ITI being in force. Figure 2 highlights the disproportion in the management of Poland's space arising from local spatial policies and implemented regional policies.

Exceeding the proposed delimitation of urban sprawl beyond the previously known delimitations is important for the implementation of spatial policy aimed at reducing the negative effects of urban sprawl. However, the authors of the FUA delimitation reserve it for the minimal version of territorial scope, which in justified cases can be extended [65]. The wider territorial scope of the proposed 
delimitation is justified both by the spatial and social specificity of urban sprawl and the possibility of instrumental impact on the causes and effects of urban sprawl. It is in the municipalities that are moved out of the core of the functional area that the costs associated with the uncontrolled expansion of buildings increase (e.g., low density of buildings resulting in greater length of construction and service of linear infrastructure). Therefore, it can be concluded that studies based on the available MOF or ITI delimitations are likely to underestimate, and thus not show real losses related to urban issues incurred by their residents. An example is the Warsaw Functional Area, in which as many as 28 communes in suburbs are at risk of urban sprawl, which were not qualified in the delimitation of FUA and ITI.

It should also be noted that the ITI delimitation was based on a method differentiated between urban areas. In addition, it was expanded territorially during negotiations with the Ministry by 49 communes (of which the largest changes took place in the case of MOF Central Subregion, an additional 27 communes were indicated). However, the ITI delimitation did not fully utilize, among other things, information on: spatial planning issues (structure of use; land development; planning documentation); technical infrastructure (local, regional, and national roads; public transport networks); housing resources; and balances of internal and foreign migration.

The quoted delimitations played an important role in managing the spatial structure of the functional area. Undoubtedly, they supported the process of implementing spatial policy and a number of actions aimed at reducing disparities in socio-economic development. However, in none of the cases mentioned above was such a specialized delimitation devoted to the issue of urban sprawl which occurred. Such a delimitation would take into account more precisely the chaotic changes in the spatial structure of suburban communes, which arose as a result of the intensification of suburbanization, with a low degree of control of these processes on the part of spatial policy.

The proposed method precisely supports the determination of the range of urban sprawl risk. The areas determined in this way may be covered by appropriate public intervention resulting from the spatial policy adapted to current needs. The postulated delimitation is characterized by significant sensitivity, resulting from the selection of research features and individual stages of the procedure, which translates into the possibility of expanded analysis and determination of marginal areas located furthest from the metropolitan core in which urban sprawl processes occur. Inhabitants of these areas bear the highest costs of urban sprawl. Various conflicts, including social, economic, spatial, etc., are also concentrated in the outer metropolitan areas [95,96]. They are also often the areas of relatively greatest development. In addition, if intervention spatial policy is launched in these areas at the right time, improvement or preservation of the undisturbed spatial structure can be expected. Metropolitan space as a result of development becomes an image of the functional system of the core center. This system, however, is subject to uninterrupted changes, including an increase in the intensity of land use inside and outside the core city by a given function, introducing new (complementary or competitive) functions or successions of functions.

An example of the practical application of the postulated method can be the use of the method of urban sprawl risk assessment in the Cracow Metropolitan Area (southern Poland) [97]. The application of the proposed method enabled the presentation of conditions and dependencies in individual territorial units in the CMA as well as the course of the phenomenon's spreading or regression. Chain indicators calculated for the entire CMA space gave a real picture of the urban sprawl risk process. The study uses data on: settlement structure (share of built-up and urbanized areas in the total area; population density of settlement areas; share of residential areas; housing growth per $1 \mathrm{k}$ residents; buildings legally completed for use per $1 \mathrm{k}$ residents); migration (balance of migration; registration from a city in the countryside); efficiency of spatial policy (planning coverage; expenses for the implementation of local plans, incurred and forecast; income derived from the local plan, i.e., planning rent; real estate tax; tax on civil law transactions; the number of administrative decisions and their structure per 10k residents); business entities (newly registered entities in the areas of agriculture and forestry, industry and construction; number of business entities per $1 \mathrm{k}$ residents of working age) 
and households (costs of commuting and return from work; costs of lost time). Used substitutes identified low-controlled transformations, based on implemented spatial policy, and suburbanization processes in the spatial structures of the examined municipalities of the metropolitan area. Taking into account the above methodological findings, a real-life urban sprawl process was presented for the CMA. Using the calculated indicators of the chain dynamics of variables representing the phenomenon, a final, aggregated indicator of the range of urban sprawl risk was generated (more on this subject in the study Urban or the Expansion of the Metropolitan Core? Analysis of the Cracow Metropolitan Area).

\section{Discussion}

The main discussion relates to the comparison of three delimitations. Nevertheless, FUA and ITI are designed to solve many problems, not just limiting urban sprawl. Therefore, the question may arise: is the mere fact of urban sprawl sufficient to change the boundaries of FUA or ITI? The method of determining the delimitation functioning in Polish spatial policy took little account of the processes of urban growth. At the same time, the overarching government document in Polish spatial policy NSDC 2030 adopts an objective of preventing urban sprawl. Thus, using the instruments (legal, fiscal, investments) for implementing spatial policy, they can be addressed to an area limited by FUA or ITI delimitations. Given that authors' delimitation generally goes beyond FUA and ITI delimitation, external areas that are particularly important may therefore be omitted. Intervention in these areas is, however, important, because they are built with indigenous buildings, which are dense. New houses, still few, are being built in agricultural areas away from the indigenous buildings, causing a loss of cohesion of the spatial structure of the commune. This distance forces local authorities to finance extensive infrastructure, which is most often quoted at the expense of urban sprawl. Therefore, the ambition of the authors' concerning delimitation is not to create a method replacing the existing ones, but to propose a parallel delimitation that could function alongside the existing ones and be used for actions of public authorities addressed specifically to control urban sprawl.

The developed methodology for delimiting areas under urban sprawl risk is characterized by significant flexibility in the use of input data as well as its application in specific planning systems. Undoubtedly, access to statistical information in the field of analysis of the lowest level spatial structure, migration or functioning of economic entities will not be a problem for researchers who want to use this method. When specifying the indicated universality or usability of the analyzed methodology, two issues should be noted. Firstly, it is a method insensitive to spatial, economic or social conditions observed in diversified spaces, and, secondly, it seems to be realistic to use it to support any local spatial policy. The characterized method has been extensively tested in Polish conditions; it was tested in all public administration units at the lowest level, NUTS5.

The authors also see the possibility of using the method in reference to other countries. This possibility results from the assessment of selected European planning systems. According to the current division of planning systems, there are six similar forms of spatial planning (i.e., in British, German, Napoleonic, Scandinavian and Central and Eastern European countries), as widely described by Newman and Thronley [98]. From a methodological point of view, the standards in these systems are significant, existing independently of the adopted planning systems. Thanks to this, it will be possible to collect information on space on the one hand, and on the other, a space will be created to use this delimitation. Generalizing, in accordance with the standards of planning procedures, existing land use is subject to legal protection, appropriate verification and positive assessment by the local authority. In all discussed planning systems, an individualized spatial policy is implemented in which the lowest-level administration units have planning authority. In all forms of spatial planning, final planning decisions are to generate optimal solutions serving the interests of the general public and the interests of the individual. An important aspect, in the light of the discussed method, is the fact that in the planning studies of the indicated systems, local development conditions are precisely determined, and in certain cases it is possible to introduce changes in these documents. It is also permissible in special cases for buildings or land development not to be specified in spatial development plans. 
It is obvious that there are significant differences between planning systems. A great example is the relation between the Germanic system, with systematized, ready-made planning solutions, and the Anglo-Saxon system, in which clear flexibility dominates in the final setting of planning solutions.

All countries implementing the discussed forms of spatial planning as the main goal of their activities include rationality of space management and prevention of urban sprawl process. The British system (England, Wales, Scotland and Ireland) uses in the process of space management a document enabling activities in space called: Planning Permission Issued by Districts and Unitary Authorities. The Germanic system (Germany, Switzerland, Austria and, partly, Eastern Europe, e.g., Poland), at the commune level, uses the land use plan (ger. Flächennutzungsplan; in Poland it is the Study of the Conditions and Directions of the Spatial Development of the Commune) and the development plan (ger. Bebaunsplan; in Poland, the Local Spatial Development Plan). The Napoleonic system is used in a significant number of European countries (i.e., France, Luxembourg, the Netherlands, Italy, Portugal, Belgium, Spain and Greece). It is a system in which priority is given by law, on the basis of which detailed legal norms are established, and rules in the field of spatial planning are determined comprehensively. The local level is required by law to have spatial planning acts, but there is no explicit level of accuracy for these studies. For example, in the spatial planning system in Spain, despite the established core of planning for individual autonomies, there is no obligation to agree the planning documentation between neighboring municipalities. In contrast, the Scandinavian system (Denmark, Sweden, Norway and Finland), based on transparent, low-complexity legislation, draws in different proportions from the Napoleonic and Germanic systems. For example, in Sweden, conducting spatial policy was based on the development of comprehensive plans (oversiktsplaner) and, at the local level, detailed spatial development plans (retail plan) and "spatial development conditions of the area". It is worth emphasizing that the local (bottom-up) level is the most important element in Sweden's planning system.

Referring to the proposed method of delimitation to functioning planning systems, it can be concluded that its application is possible in various European countries because all the indicated countries implement spatial policy at the local level using appropriate factual planning documentation. Furthermore, the methodology being analyzed can directly retrieve the necessary data from the local planning system, and then the system can be appropriately modified to reduce unwanted phenomena in space.

\section{Conclusions}

The proposed delimitation is based on two key stages. The first allows determining the maximum range of research, and the second stage involves assessing the probability of urban sprawl. An important assumption of the first stage is to focus research on communes located within the assumed radius. This radius was proposed based on real time accessibility to the core city as the main area of employment concentration. The feasibility of accessibility results from taking into account the real route and congestion in the study. The second stage of the delimitation proposal, on the other hand, takes into account the range of variables directly referring to the specificity of urban sprawl. Hence, the subjects of methodological operationalization were variables grouped into three areas: settlement structure, migration processes, and spatial policy efficiency. In conclusion, we can point to several strengths of the method and to its limitations. The framework of such a method may determine the possibility of its use in the delimitation of urban sprawl risk in countries other than Poland. Therefore, the strengths include:

universality of the method-caused by the inclusion of statistical data that is collected in most countries. In addition, the methodology is not complicated in the field of computational work, which allows it to be used also by public administration employees dealing with the issues of broadly understood spatial management. The method makes it possible to determine the phenomenon within the administrative boundaries of the unit, giving the opportunity to modify, for example, local spatial policy threatened by the phenomenon of urban sprawl. Furthermore, 
it can be useful when determining integrated development strategies, e.g., for metropolitan areas, in the field of comprehensive assessment of occurring phenomena in space.

- the use of medium-term indexes of chain dynamics and a moving average-enabling "smoothing" behavior in variable time. This allows for objective identification of the direction of changes and assessment of the attributes assigned to urban sprawl.

- $\quad$ considering the method the efficiency of spatial policy as a necessary condition for identifying urban sprawl. Development processes take place in various spatial forms. Hence, some areas are not built up, leaving empty spaces between developments. This creates an inconsistent spatial structure attributed to urban sprawl. However, such a structure, when it is the implementation of a plan, in which the next planned investments will fill the vacant areas, cannot be defined as uncontrolled. In fact, it takes part in the planned process. On the other hand, a situation may arise in which the same spatial structure was created as the sum of individual investments carried out by various entities, in the absence of location coordination by public authorities. This is often the case in Poland in the absence of spatial plans in the commune. In this situation, we are dealing with inefficient spatial policy, resulting in the creation of a spatial structure with attributes connected to urban sprawl. Therefore, the strength of the proposed method is to take into account the assessment of spatial policy efficiency in coordinating spatial development. In addition, the method uses information contained in, among other things, planning documents, and these are developed in a variety of planning systems, including the Germanic, Scandinavian, Napoleonic and British systems.

However, among the limitations of the method we distinguish:

- the use of data on migration from cities that do not clearly indicate the city from which the population migrates. In the case of Poland, this problem is compounded by the polycentric structure of Poland, where many capitals of the regions are located close to each other. This phenomenon is particularly observed in the southern part of Poland. As a result, in the case of communes remote from the city, we do not know exactly whether the migration is from the capital of one or another nearby city. Therefore, this method limitation was tried to be amortized by adopting the maximum range of the phenomenon (stage 1). It seems that the application of the method to other countries with a polycentric structure of the country and small distances between cities must obligatorily include setting the maximum range of research, while in monocentric countries or those with large distances between cities, this stage may be optional.

- the problem of spatial policy efficiency assessment. In the case of the proposed method, data collected in Poland was used, while discussing that administrative decisions document the lack of spatial policy, as they are issued in the absence of spatial plans in the commune. The administrative decision is therefore individual to the investment and does not take into account a coherent vision of territory development. Therefore, one cannot say that it is an instrument of policy efficiency, which is why it was treated as a de-stimulant in this research. However, an instrument of efficiency may be a spatial plan, and the higher the coverage of a commune's area with plans, the more coherent and thought out local spatial policy becomes. Therefore, if the method is used in other countries, the approach to quantifying the efficiency of spatial policy must be individually adopted.

- the dominance of quantitative techniques, which in full implementation of research outside Poland may not always result in correct evaluation. During the internationalization of the method, the researcher will be forced to consider the specific local conditions of the studied country.

The practical significance of the presented research is expressed primarily in the usefulness of the proposed delimitation for conducting spatial policy aimed at reducing the effects of urban sprawl. The current delimitations functioning in Polish spatial policy are not satisfactory for counteracting the spontaneous spread of buildings to suburbs and the effects of this process. In Polish spatial policy, it is possible to designate threatened areas in urban sprawl in accordance with the applicable 
geographical and territorial division. Such delimitation must, however, honor the maximum territorial scope of the phenomenon postulated in the research, in which uncoordinated changes in the settlement structure occur as a result of socio-economic processes. Therefore, in regional planning and strategic documentation, which formulates objectives related to counteracting urban sprawl, while pointing to instruments for achieving such goals, it is necessary to specify the extent of spontaneous expansion of buildings, and the proposed methodology may be used here. The suggested system reorganization should also find application in nationwide studies (i.e., the NSDC 2030).

The research also encourages the formulation of recommendations for Polish spatial policy. It seems justified to redefine the areas of current support for municipalities around large cities. On the one hand, the current FUA borders in the implementation of ITIs do not limit the areas that require support through cooperation mechanisms guaranteeing the implementation of joint, valuable projects. On the other hand, the broader territorial proposal for the delimitation of urban sprawl makes it possible to designate an area where the potential use of FUA and ITI instruments could result in the creation of spatially and functionally coherent urban areas.

Taking into account other practical aspects of the study, there is a need for legislative changes in the field of official statistics and institutions collecting spatial data. The changes should take into account the extension of the scope of collection of detailed statistical data, reflecting spatial processes and synchronization of public statistics with separate spatial databases operating in Poland. The next stage is widespread availability in public statistics of synchronized building data, e.g., in the form of GRID (a form of space mapping in GIS).

Author Contributions: Conceptualization, P.L.; methodology, P.L. and A.H.; software, A.H.; validation, A.H.; formal analysis, P.L. and A.H.; investigation, P.L. and A.H.; resources, P.L. and A.H.; data curation, A.H.; writing —original draft preparation, P.L. and A.H.; writing—review and editing, P.L. and A.H.; visualization, A.H.; supervision, project administration and funding acquisition, P.L. All authors have read and agreed to the published version of the manuscript.

Funding: This research was funded by the National Science Centre, Poland; grant no. UMO-2016/23/D/HS4/02961, ("Financial Mechanisms in the Economy Resulting from the Phenomenon of Urban Sprawl").

Conflicts of Interest: The authors declare no conflict of interest.

\section{References}

1. Parysek, J. Wprowadzenie do Gospodarki Przestrzennej; UAM: Poznań, Poland, 2007; ISBN 978-83-2321-808-1.

2. Górka, A. Threats to Rural Landscape and Its Protection in Poland. Environments 2018, 5, 109. [CrossRef]

3. Nowacka, E. Władza Samorzadu Lokalnego, 1st ed.; LexisNexis: Warsaw, Poland, 2012; ISBN 978-83-7806-672-9.

4. Domański, R. Gospodarka Przestrzenna: Podstawy Teoretyczne; PWN: Warsaw, Poland, 2006; ISBN 978-83-0114-800-3.

5. Korenik, S.; Słodczyk, J. Podstawy Gospodarki Przestrzennej-Wybrane Aspekty, Wyd.; Wrocław University of Economics: Wrocław, Poland, 2005.

6. Hołuj, A. Internalizacja ekonomicznych efektów zewnętrznych na obszarach dotkniętych procesem urban sprawl: Przykład Krakowskiego Obszaru Metropolitalnego. Biuletyn Polskiej Akademii Nauk. Komitet Przestrzennego Zagospodarowania Kraju 2018, 270, 67-81.

7. Hołuj, A.; Lityński, P. Conditions and Improvements Impacting Urban Sprawl in Poland. Studia Regionalia 2015, 43 .

8. Wassmer, R.W. An Economic Perspective on Urban Sprawl: With an Application to the American West and a Test of the Efficacy of Urban Growth Boundaries; California State University of Research: Long Beach, CA, USA, 2002; p. 3.

9. Nechyba, T.J.; Walsh, R.P. Urban Sprawl. J. Econ. Perspect. 2004, 18, 177-200. [CrossRef]

10. Barnes, K.B.; Morgan, J.M.; Roberge, M.C.; Lowe, S. Sprawl Development: Its Patterns, Consequences, and Measurement; Towson University: Baltimore, MD, USA, 2001.

11. Wilson, E.H.; Hurd, J.D.; Civco, D.L.; Prisloe, S.; Arnold, C. Development of a geospatial model to quantify, describe and map urban growth. Remote Sens. Environ. 2003, 86, 275-285. [CrossRef] 
12. Roca, J.; Burnsa, M.C.; Carreras, J.M. Monitoring urban sprawl around Barcelona's metropolitan area with the aid of satellite imagery. In Proceedings of the Geo-Imagery Bridging Continents XXth ISPRS Congress, Istanbul, Turkey, 12-23 July 2004.

13. Sudhira, H.S.; Ramachandra, T.V. Characterising urban sprawl from remote sensing data and using landscape metrics. In Proceedings of the 10th International Conference on Computers in Urban Planning and Urban Management, Iguassu Falls, Brazil, 11-13 July 2007.

14. Angel, S.; Parent, J.; Civco, D. Urban sprawl metrics: An analysis of global urban expansion using GIS. In Proceedings of the ASPRS 2007 Annual Conference, Tampa, FL, USA, 7-11 May 2007.

15. Bullard, D.R.; Johnson, G.S.; Torres, A.O. Sprawl City: Race, Politics and Planning in Atlanta; Island Press: Washington, DC, USA, 2000; ISBN 978-1559637909.

16. Duany, A.; Plater-Zyberk, E.; Speck, J. Suburban Nation: The Rise of Sprawl and the Decline of the American Dream; North Point Press: New York, NY, USA, 2000; ISBN 978-0865477506.

17. Phelps, N.A.; Parsons, N.; Ballas, D.; Dowling, A. Post-Suburban Europe: Planning and Politics at the Margins of Europe's Capital Cities; Palgrave Macmillan: New York, NY, USA, 2006; ISBN 978-0-230-00212-8.

18. Kyvelou, S.S.; Gourgiotis, A. Landscape as Connecting Link of Nature and Culture: Spatial Planning Policy Implications in Greece. Urban Sci. 2019, 3, 81. [CrossRef]

19. Galster, G.; Hanson, R.; Wolman, H.; Coleman, S.; Freihage, J. Wrestling sprawl to the ground: Defining and measuring an elusive concept. Hous. Policy Debate 2001, 12, 681-717. [CrossRef]

20. Bhatta, B. Analysis of Urban Growth and Sprawl from Remote Sensing Data. In Advances in Geographical Information Science; Springer: Berlin/Heidelberg, Germany, 2010; ISBN 978-3-642-05299-6.

21. Arribas-Bel, D.; Nijkamp, P.; Scholten, H. MultiDimensional Urban Sprawl in Europe: A Self-Organizing Map Approach. In Proceedings of the 50th Congress of the European Regional Science Association: Sustainable Regional Growth and Development in the Creative Knowledge Economy, Jonkoping, Sweden, 19-23 August 2010.

22. Perrsky, J.; Wiewel, J. Urban Decentralization, Suburbanization, and Sprawl: An Equity Perspective. In Urban Economics and Planning; Brooks, N., Donaghy, K., Knaap, G.J., Eds.; Oxford University Press: New York, NY, USA, 2012; ISBN 978-0195380620.

23. Lisowski, A.; Grochowski, M. Procesy Suburbanizacji. Uwarunkowania, Formy, Konsekwencje; 240/2009; Biuletyn KPZK: Warsaw, Poland, 2009; pp. 216-280.

24. Herold, M.; Hemphill, J.; Dietzel, C.; Clarke, K.C. Remote sensing derived mapping to support urban growth theory. In Proceedings of the ISPRS Joint Conference 3rd International Symposium Remote Sensing and Data Fusion Over Urban Areas, and 5th International Symposium Remote Sensing of Urban Areas (URS 2005), Tempe, AZ, USA, 14-16 March 2005.

25. Lowry, J.H.; Lowry, M.B. Comparing spatial metrics that quantify urban form. Comput. Environ. Urban Syst. 2014, 44, 59-67. [CrossRef]

26. Nedovic-Budic, Z.; Knaap, G.J.; Shahumyan, H.; Wiliams, B.; Slaev, A. Measuring urban form at community scale: Case study of Dublin. Cities 2016, 55, 148-164. [CrossRef]

27. Hamidi, S.; Ewing, R. A longitudinal study of changes in urban sprawl between 2000 and 2010 in the United States. Landsc. Urban Plan. 2014, 128, 72-82. [CrossRef]

28. Fulton, W.; Pendall, R.; Nguyen, M.; Harrison, A. Who Sprawls Most: How Growth Patterns Differ across the United States; The Brookings Institution: Washington, DC, USA, 2001.

29. Kahn, M. Does sprawl reduce the black/white housing consumption gap? Hous. Policy Debate 2001, 12, 77-86. [CrossRef]

30. Lopez, R.; Hynes, H.P. Sprawl in the 1990s: Measurement, distribution and trends. Urban Aff. Rev. 2003, 38, 325-355. [CrossRef] [PubMed]

31. Ewing, R.; Pendall, R.; Chen, D. Measuring Sprawl and Its Impact; Smart Growth America: Washington, DC, USA, 2002.

32. Wolman, H.; Galster, G.; Hanson, R.; Ratcliffe, M.; Furdell, K.; Sarzyński, A. The Fundamental Challenge in Measuring Sprawl: Which Land Should Be Considered? Prof. Geogr. 2005, 57, 94-105.

33. Dziewoński, K.; Kosiński, L. Rozmieszczenie ludności w Polsce w XX w. Przeglad Geograficzny 1964, 36, 3-36.

34. Iwanicka-Lyra, E. Delimitacja aglomeracji wielkomiejskich w Polsce. In Prace Geograficzne; IGiZP PAN: Warsaw, Poland, 1969; p. 76. 
35. Leszczycki, S.; Eberhardt, P.; Heřman, S. Aglomeracje miejsko-przemysłowe w Polsce 1966-2000. In Biuletyn; KPZK PAN: Warsaw, Poland, 1967; p. 67.

36. Gontarski, Z. Delimitacja obszarów metropolitalnych w Polsce. In Statystyka Terenowa; GUS: Warsaw, Poland, 1972; Volume 8, pp. 55-63.

37. Gontarski, Z. Obszary Metropolitalne w Polsce; Biuletyn KPZK PAN: Warsaw, Poland, 1982; Volume 109, pp. 25-41.

38. Potrykowska, A. Funkcjonalne regiony miejskie w krajowym systemie osadniczym. In WspółCzesne Przemiany Regionalnych Systemów Osadniczych w Polsce; Prace Geograficzne, 152; Korcelli, P., Gawryszewski, A., Eds.; Instytut Geografii i Przestrzennego Zagospodarowania: Warsaw, Poland, 1989; pp. 55-76.

39. Swianiewicz, P.; Klimska, K. Społeczne i polityczne zróżnicowanie aglomeracji w Polsce-Waniliowe centrum, mozaika przedmieść. Prace Studia Geograficzne 2005, 35, 45-70.

40. Smętkowski, M. Delimitacja obszarów metropolitalnych-Nowe spojrzenie. In Rozwój, Region, Przestrzeń; Gorzelak, G., Tucholska, A., Eds.; Ministerstwo Rozwoju Regionalnego (EUROREG): Warsaw, Poland, 2007; pp. 215-233.

41. Smętkowski, M.; Jałowiecki, B.; Gorzelak, G. Obszary Metropolitalne w Polsce: Problemy Rozwojowe i Delimitacja; Raporty i Analizy EUROREG 1/2009; EUROPEG: Warsaw, Poland, 2009.

42. Ratzel, F. Die Gesetze des raumlichen Wachstums der Staaten. Petermanns Mitteilungen 1896, 42, 97-107.

43. Hoover, E.M. The Location of Economic Activity; McGraw-Hill: New York, NY, USA, 1948.

44. Friedman, J.; Alonso, W. Regional Development and Planning; MIT Press: Cambridge, UK, 1966.

45. Perroux, F. Note sur la notion de "pôle de croissance". Econ. Appliquée 1955, 8, 307-316.

46. Davin, L.E. O filozofii gospodarki regionalnej. Biuletyn KPZK PAN 1968, 48, 187-221.

47. Klaassen, L. Area Economic and Social Redevelopment: Guidelines for Programmes; OECD: Paris, France, 1965.

48. Grzeszczak, J. Koncepcje Polaryzacyjne w Przestrzennym Zagospodarowaniu Kraju. Na przykładzie Francji; Studia KPZK PAN: Warsaw, Poland, 1971; Volume 36, pp. 4-19.

49. Berry, B.J.L.; Conkling, E.C.; Ray, D.M. The Geography of Economic Systems; Prentice-Hall, Inc.: Englewood Cliffs, NJ, USA, 1976.

50. Winiarski, B. Polityka Regionalna; PWE: Warsaw, Poland, 1976.

51. Kukliński, A. (Ed.) Diagnoza Stanu Gospodarki Przestrzennej Polski. Wstępne Wyniki Badań; Biuletyn KPZK PAN: Warsaw, Poland, 1983; Volume 123, Available online: http://www.euroreg.uw.edu.pl/dane/web_euroreg_ publications_files/3433/18._wspczesne_problemy_gospodarki_przestrzennej_polski.pdf (accessed on 10 February 2020).

52. Zagożdżon, A. Kilka uwag o obszarach problemowych. In Gospodarka Przestrzenna, Region, Lokalność, 1st ed.; Jałowiecki, B., Kukliński, A., Eds.; Biuletyn KPZK: Warsaw, Poland, 1988; Volume 138, pp. 137-147.

53. Gorzelak, G. Rozwój Regionalny Polski w Warunkach Kryzysu i Reformy, Rozwój Regionalny-Rozwój Lokalny_Samorzad Terytorialny; UW 14; IGP: Warsaw, Poland, 1989.

54. Churski, P.; Hauke, J. Obszary problemowe w Polsce w układzie jednostek NTS. In Możliwości i Ograniczenia Zastosowań Metod Badawczych w Geografii Społeczno-Ekonomicznej i Gospodarce Przestrzennej; Rogacki, H., Ed.; Bogucki Wydawnictwa Naukowe: Poznań, Poland, 2002; pp. 161-176.

55. Bański, J. Typy ludnościowych obszarów problemowych. In Społeczne Problemy wsi, Studia Obszarów Wiejskich; Bański, J., Rydz, E., Eds.; Komisja Obszarów Wiejskich PTG: Warsaw, Poland, 2002; pp. 41-52. ISSN 1642-4689.

56. Jadczyszyn, J. Regionalne zróżnicowanie obszarów problemowych rolnictwa (OPR) w Polsce. In Instytut Uprawy, Nawożenia i Gleboznawstwa w Puławach; 2009; Volume 163, ISBN 978-83-7562-041-2. Available online: http://opr.iung.pulawy.pl/publikacje/IU-163.pdf (accessed on 5 February 2020).

57. Komornicki, T.; Śleszyński, P. Typologia obszarów wiejskich pod względem powiązań funkcjonalnych i relacji miasto-wieś. In Analiza Zróżnicowania i Perspektyw Rozwoju Obszarów Wiejskich w Polsce do 2015 Roku; Bański, J., Ed.; Studia Obszarów Wiejskich: Warsaw, Poland, 2009; pp. 9-37.

58. Eberhardt, P. Studia nad problematyką delimitacji aglomeracji miejskich w Polsce. In Warsawa jako przedmiot badań w geografii społeczno-ekonomicznej, Prace Geograficzne; Węcławowicz, G., Ed.; IGiPZ PAN: Warsaw, Poland, 2002; pp. 55-64.

59. Eberhardt, P.; Gontarski, Z.; Siemiński, J. Koncepcje delimitacji aglomeracji miejskich w Polsce. Biuletyn KPZK PAN 1973, 79, 187-217. 
60. Rykiel, Z. Koncepcje i delimitacje wielkomiejskich form osadniczych w Polsce. In Wspótczesne Formy Osadnictwa Miejskiego i ich Przemiany; XV Konwersatorium Wiedzy o Mieście; Jażdżewska, I., Ed.; Uniwersytet Łódzki, Łódzkie Towarzystwo Naukowe: Łódź, Poland, 2002; pp. 9-19.

61. Markowski, T.; Marszał, T. Metropolie, Obszary Metropolitalne, Metropolizacja. Problemy i Pojęcia Podstawowe; KPZK PAN: Warsaw, Poland, 2006.

62. Czyż, T. Koncepcja aglomeracji miejskiej i obszaru metropolitalnego w polskiej geografii i miast. In Aglomeracje Miejskie w Polsce na Przełomie XX i XXI Wieku; Problemy rozwoju, przekształceń strukturalnych i funkcjonowania; Maik, W., Ed.; Wyższa Szkoła Gospodarki w Bydgoszczy: Bydgoszcz, Poland, 2009; pp. 15-30.

63. Korcelli, P. Obszary metropolitalne a funkcjonalne obszary miejskie. In Miasto. Ksiega Jubileuszowa w 70. Rocznice Urodzin Profesora Stanistawa Liszewskiego; Kaczmarek, S., Ed.; University of Lodz Press: Lodz, Poland, 2011; pp. 43-50.

64. Śleszyński, P. Delimitacja Miejskich Obszarów Funkcjonalnych stolic województw. Przegląd Geogr. 2013, 85, 173-197. [CrossRef]

65. Goerlich Gisbert, F.J.; Cantarino Martí, I.; Gielen, E. Clustering cities through urban metrics analysis. J. Urban Design 2017, 22, 689-708. [CrossRef]

66. Liang, J.; Li, F.; Mao, L. Review of the methods of delimitation for the spatial scope of urban agglomeration. In Proceedings of the 18th International Conference on Geoinformatics: GIScience in Change, Geoinformatics 2010, Beijing, China, 18-20 June 2010; pp. 18-20. [CrossRef]

67. Tellier, L.-N.; Gelb, J. An Urban Metric System based on space-economy: Foundations, and implementation. Reg. Sci. Policy Pract. 2018, 10, 145-160. [CrossRef]

68. Knaap, G.J.; Song, Y.; Ewing, R.; Clifton, K. Seeing the Elephant: Multidisciplinary Measure of Urban Sprawl. J. Plan. 2005, 1-46. Available online: https://pdfs.semanticscholar.org/7881/ d6145311eb3d2d64c333a4ffc6526df817d0.pdf (accessed on 5 February 2020).

69. Glaeser, E.L.; Kahn, M.E. Sprawl and Urban Growth; NBER Working Paper Series No. 9733; Harvard Institute of Economic Research: Cambridge, MA, USA, 2003; Available online: http://www.econ.brown.edu/Faculty/ henderson/sprawl.pdf (accessed on 5 February 2020).

70. Lityński, P. The correlation between urban sprawl and the local economy in Poland. Urbani Izziv 2016, 27, 86-96. [CrossRef]

71. Torrens, P.M.; Alberti, M. Measuring Sprawl (CASA Working Papers 27); Centre for Advanced Spatial Analysis (UCL): London, UK, 2000.

72. Frenkel, A.; Ashkenazi, M. Measuring urban sprawl: How can we deal with it? Environ. Plan. B Plan. Design 2008, 35, 56-79. [CrossRef]

73. Pieniążek, M.; Rogalińska, D. Suburbanizacja jako wyzwanie badawcze dla statystyki regionalnej. Studia $i$ Materiaty Miscellanea Oeconomicae 2015, 4, 197-206.

74. Tellier, L.-N. Économie Spatiale: Rationalité Économique de l'espace Habité; Gaëtan, M., Ed.; 1985; ISBN 2-89105-501-2. Available online: https://www.erudit.org/fr/revues/cgq/1994-v38-n104-cgq2676/022445ar.pdf (accessed on 5 February 2020).

75. Tellier, L.-N. Urban World History. An Economic and Geographical Perspective, 2nd ed.; Springer Nature: Basel, Switzerland, 2019; ISBN 978-3-030-24841-3.

76. Tellier, L.-N. A Challenge for Regional Science: Revealing and Explaining the Global Spatial Logic of Economic Development. J. Reg. Sci. 1997, 76, 371-384. [CrossRef]

77. Tellier, L.-N.; Polanski, B. The Weber Problem: Frequency of Different Solution Types and Extension of Repulsive Forces and Dynamics Processes. J. Reg. Sci. 1989, 29, 387-405. [CrossRef]

78. Tellier, L.-N.; Vertefeuille, C. Understanding Spatial Inertia: Centre of Gravity, Population Densities, the Weber Problem and Gravity Potential. J. Reg. Sci. 1995, 35, 155-164. [CrossRef]

79. Ottaviano, G.; Thisse, J.-F. New Economic Geography: What about the N? Environ. Plan. A 2005, 37, $1707-1725$. [CrossRef]

80. O'Sullivan, A. Urban Economics; McGraw-Hill: New York, NY, USA, 2012; ISBN 978-0073511474.

81. Śleszyński, P. Dostępność ekonomiczna miast wojewódzkich w świetle kosztów dojazdu samochodem osobowym. Prace Komisji Geografii Komunikacji PTG 2017, 20, 7-18.

82. Nelson, A.C.; Duncan, J.B. Growth Management Principles and Practices; Planners Press: New York, NY, USA, 1995. 
83. Schneider, A.; Woodcock, C.E. Compact, dispersed, fragmented, extensive? A comparison of urban growth in twenty-five global cities using remotely sensed data, pattern metrics and census information. Urban Stud. 2008, 45, 659-692. [CrossRef]

84. Heffner, K. Proces suburbanizacji a polityka miejska w Polsce. In Miasto-Region-Gospodarka w Badaniach Geograficznych. W Stulecie Urodzin Profesora Ludwika Straszewicza; Marszał, T., Ed.; Wydawnictwo Uniwersytetu Łódzkiego: Łódź, Poland, 2016.

85. Lang, R.E. Office Sprawl: The Evolving Geography of Business; Brookings Institution: Washington, DC, USA, 2000.

86. Glaeser, E.L.; Kolko, J.; Saiz, A. Consumer city. J. Econ. Geogr. 2001, 1, 27-50. [CrossRef]

87. Crane, R.; Chatman, D.G. Traffic and Sprawl: Evidence from US Commuting from 1985-1997; University of Southern California: Los Angeles, CA, USA, 2003; Volume 6.

88. Lavalle, C.; Demicheli, L.; Kasanko, M.; McCormick, N.; Barredo, J.; Turchini, M.; Caetano, M. Towards an Urban Atlas: Assessment of Spatial Data on 25; Environmental Issue Report; European Environment Agency: Copenhagen, Denmark, 2002; Available online: http://projects.mcrit.com/esponfutures/documents/European\%20Studies/EEA\%20(2002)\%20Towards\% 20an\%20urban\%20atlas,\%20Assessment\%20of\%20spatial\%20data.pdf (accessed on 5 February 2020).

89. Pumain, D. Urban sprawl: Is there a French case. In Urban Sprawl in Western Europe and the United States; Asghate: Aldershot, UK, 2004; pp. 137-157.

90. Lityński, P.; Hołuj, A. Urban sprawl costs: The valuation of households' losses in Poland. J. Settl. Spat. Plan. 2017, 8, 11-35. [CrossRef]

91. Lityński, P.; Zotic, V.; Hołuj, A. Polish urban sprawl. An economic perspective. J. Settl. Spat. Plan. 2015, 6, 95-105.

92. Diekman, A.; Jann, B. Benford's Law and Fraud Detection. Facts and Legends. Ger. Econ. Rev. 2010, 11, 397-401. [CrossRef]

93. Bul, R.; Walaszek, M. Dojazdy do pracy i szkół jako podstawowe kryterium delimitacji obszarów funkcjonalnych miast. Rozwój Regionalny Polityka Regionalna 2015, 29, 119-138. [CrossRef]

94. Kryteria Delimitacji Miejskich Obszarów Funkcjonalnych Ośrodków Wojewódzkich; Ministerstwo Rozwoju Regionalnego: Warsaw, Poland, 2013.

95. Manganelli, B.; Murgante, B.; Saganeiti, L. The Social Cost of Urban Sprinkling. Sustainability 2020, 12, 2236. [CrossRef]

96. Hołuj, D.; Hołuj, A. Mechanisms of densification of the city in the neoliberal economy-A case study: The surroundings of the eastern part of the former airport runway Rakowice-Czyżyny in Cracow. Bull. Geogr. Socioecon. Ser. 2015, 27, 81-93. [CrossRef]

97. Hołuj, A. Urban or the expansion of the metropolitan core? Analysis of the Cracow Metropolitan Area. In Funkcjonalne Miasto w Teorii i Praktyce na Przykładzie Krakowa i Krakowskiego Obszaru Metropolitalnego; Kudłacz, T., Musiał-Malago, M., Eds.; Wydawnictwo Uniwersytetu Ekonomicznego w Krakowie: Krakow, Poland, 2018; pp. 74-83.

98. Newman, P.; Thornley, A. Urban Planning in Europe: International Competition, National Systems, and Planning Projects; Routledge: London, UK, 1996; ISBN 0-203-73618-4.

(C) 2020 by the authors. Licensee MDPI, Basel, Switzerland. This article is an open access article distributed under the terms and conditions of the Creative Commons Attribution (CC BY) license (http://creativecommons.org/licenses/by/4.0/). 